\title{
Prognostic significance of BAALC overexpression in patients with $A M L$ during the posttransplant period
}

\author{
Alena I. Shakirova, Ildar M. Barkhatov, Anna I. Churkina, Ivan S. Moiseev, Tatiana L. Gindina, Sergey N. Bondarenko, \\ Boris V. Afanasyev \\ R. Gorbacheva Memorial Institute of Children Oncology, Hematology and Transplantation, The First St. Petersburg State \\ I. Pavlov Medical University, St. Petersburg, Russia
}

Dr. Ildar M. Barkhatov, R. Gorbacheva Memorial Institute of Children Oncology, Hematology and Transplantation, First St. Petersburg State I. Pavlov Medical University,

Roentgen St. 12, 197022, St. Petersburg, Russia
Phone: +7 (911) 7782785

E-mail: i.barkhatov@gmail.com

\section{Summary}

Acute myeloid leukemia (AML) is a heterogenous clonal blood disease of a neoplastic origin. There are challenging issues for the intermediate-risk AML group, which is defined as non-homogeneous due to a variety of gene mutations (FLT3, NPM1, CEBPA, etc.), prediction of differential clinical course, relapse risk, and selection of adequate therapy. In this context, a search for new molecular markers with sufficient prognostic value for the relapse risk estimation in AML cases with no detectable cytogenetic abnormalities represents a high-priority task for clinical molecular oncohematology. We analyzed prognostic significance of BAALC (Brain And Acute Leukemia, Cytoplasmic) gene overexpression in 93 AML patients during the posttransplant period, in order to estimate feasibility of BAALC expression level monitoring, to predict the relapse risk, and to evaluate sensitivity and specificity of BAALC gene expression assay, to the purpose of minimal residual disease (MRD) monitoring. BAALC expression was determined by quantitative real-time polymerase chain reaction in fresh bone marrow samples. Patients were dichotomized at $B A A L C$ 's individual and general cut-off into low and high expressers. We have concluded that $B A A L C$ overexpression above both individual and common cut-off levels is recognized as a prognostically significant factor for posttransplant relapse risk estimation, overall survival and relapse-free survival. A more detailed analysis of BAALC as a marker for estimation of therapeutic efficiency was performed. We have also compared its sensitivity to the reference techniques for minimal residual disease monitoring (i.e., qPCR-based detection of chimeric gene transcripts), showing inferior sensitivity of such approach to MRD detection in post-transplant period, at least, for our study group. Serial BAALC monitoring may be recommended for clinical relapse prediction during the post-transplant period in AML patients.

\section{Keywords}

Acute myeloblastic leukemia, BAALC, gene expression, clinical prognosis, minimal residual disease. 


\section{Introduction}

Acute myeloid leukemia (AML) is a clinically heterogenous clonal blood malignancy. Stratification of the patients into certain AML risk group is primarily based on the presence or absence of cytogenetic aberrations specific to certain leukemic cell clones [1]. Meanwhile, there are challenging issues for the intermediate-risk AML group, which is defined as a non-homogeneous clinical entity, due to a variety of encountered gene mutations (FLT3, NPM1, CEBPA, etc.) coupled to appropriate differences in clinical course, relapse risk, and adequate treatment choice. Allogeneic transplantation of hematopoietic stem cells (allo-HSCT) was proven to be an optimal approach to AML therapy [2]. However, leukemia relapses develop in 33-78\% of AML patients following allo-HSCT, mainly, due to post-treatment persistence of residual leukemic cells in hematopoietic tissues defined as minimal residual disease (MRD). Therefore, a search for new molecular markers able to predict the relapse risk in AML cases, especially those lacking evident cytogenetic abnormalities, represents a high-priority task for clinical molecular oncohematology.

In this respect, the $B A A L C$ (brain and acute leukemia, cytoplasmic) gene is a useful molecular marker showing enhanced expression in AML malignant cells, being also associated with unfavorable disease prognosis after the induction chemotherapy $[3,4,5]$. In earlier studies, the high $B A A L C$ expression level was observed as a single abnormality in AML patients associated with chromosome 8 trisomy [6]. Later on, the $B A A L C$ overexpression was shown to be a negative prognostic factor in AML patients with normal karyotype (NK-AML) [7, 8]. The cases of leukemia with primary chemoresistance, high relapse risk and lower overall survival (OS) rates were more common among the patients with $B A A L C$ over-expression, if compared to the patient groups with low BAALC expression [7, 9].

$B A A L C$ gene is located in the $8 \mathrm{q} 22.3$ locus (chromosome 8). In normal hematopoiesis, $B A A L C$ expression is limited by a population of early CD34+ progenitor cells, being, however, associated with the most immature blasts in acute leukemia (AL) $[7,8]$. The BAALC overexpression frequency is about 40-60\%, similarly to other AML expression markers. But, despite such high prevalence, the functional role of $B A A L C$ gene product was only recently specified for the leukemia pathogenesis. Morita and co-authors [10] have shown that $B A A L C$ overexpression in leukemic cell lines is associated with a cell cycle progression through the ERK-kinase intracellular signaling cascade activation. In addition, more abundant BAALC protein in the cytoplasm interacts with KLF4 transcription factor, thus causing blockage of KLF4 nuclear transport and inhibition of the specific tumor cell suppression. At the same time, a constitutive BAALC expression/activation in normal hematopoietic stem cells does not influence their proliferative activity [11]. This fact suggests that an additional genetic defect may promote AML in patients with over-expressed $B A A L C$ associated with a relapse before allo-HSCT. Ability of BAALC to block myeloid differentiation of hematopoietic stem cells, due to interaction with HoxA9 oncogene, could be one of such tumor-promoting factors [11]. Hence, some recent data point to certain inter- relations between the $B A A L C$ over-expression and functional changes in malignant AML cells, thus assisting the disease progression.

Interestingly, $B A A L C$ expression is regulated by the SP1/ $\mathrm{NF}-\kappa \mathrm{B}$ transcription factor complex. Its pharmacological inhibitor (Bortezomib) reduces the BAALC transcripts abundance in AML cell line KG1a [12]. Suppression of BAALC expression by shRNA in KG1a cells leads to a decrease of the proliferative activity and apoptosis induction [13]. Further studying of the complex genetic abnormalities, associated with intracellular signaling in BAALC-positive AML, may assist both with selection of therapeutic approach, and opens new opportunities in targeted therapy of resistant AML and prevention of post-transplant relapses.

The aim of this study was to analyze prognostic significance of $B A A L C$ gene over-expression in AML patients during the post-transplant period, in order to estimate feasibility of $B A A L C$ expression level monitoring, to predict the relapse risk, and to evaluate sensitivity and specificity of BAALC gene expression assays, as a tool for MRD monitoring.

\section{Patients and Methods}

\section{Clinical data}

The study included ninety-three AML patients who have undergone 94 allo-HSCTs (one transplantation was repeated) at the R. Gorbacheva Memorial Institute Research Institute of Children Oncology, Hematology and Transplantation (St. Petersburg) from 2010 to 2014. A median follow-up time after HSCT was 7 ( 0.5 to 52.5 ) months. The detailed patient characteristics are shown in Table 1. Bone marrow sampling for molecular studies was performed before and after allo-HSCT on 15-720 days posttransplant.

\section{RNA extraction and reverse transcription}

RNA was isolated from the fresh bone marrow samples by the guanidine-phenol-chloroform extraction method using the "Ribo-zol-D" kit reagent (InterLabService, Russia), according to the manufacturer's instructions.

Eleven microliters of extracted RNA were used for reverse transcription and cDNA synthesis, being performed with RevertAid First Strand cDNA Synthesis Kit (LifeTechnologies, USA).

\section{Quantitative evaluation of $B A A L C$ gene expression}

For each cDNA sample, multiplex PCR was performed for $B A A L C$ and $A B L$ genes. The reaction conditions were as follows: $10 \mu \mathrm{l}$ of PCR reaction mixture (“Syntol”, Russia), containing dNTP mix $2.5 \mathrm{mM}$ each, 10xPCR buffer, 5 Units of Taq-DNA polymerase and $2.5 \mu \mathrm{l}$ of $25 \mathrm{mM} \mathrm{MgCl}_{2}$, supplemented with 7 pmol of each gene-specific primers, 5 pmol of Taqman probes for the both $B A A L C$ and $A B L$ genes. The primer and TaqMan probe sequences for the quantitative real-time PCR are shown in Table 2. Finally, $5 \mu \mathrm{l}$ of cDNA template, or calibrator for BAALC and ABL ("Inogene", Russia) were added to the individual tubes, at a total PCR reaction volume of $25 \mu \mathrm{l}$. Quantitative real-time PCR was performed 
Table 1. Clinical characteristics of the patients

\begin{tabular}{|c|c|c|}
\hline Parameters & \multicolumn{2}{|c|}{ Number of cases (Percentages of total) } \\
\hline $\begin{array}{l}\text { Patient number } \\
\text { BAALC status pre-transplant: } \\
\text { BAALC-positive AML } \\
\text { BAALC-negative AML } \\
\text { Not determined }\end{array}$ & \multicolumn{2}{|l|}{$\begin{array}{l}15 \text { (16.1\%) } \\
19(20.4 \%) \\
59(63.5 \%)\end{array}$} \\
\hline Age, years; median & \multicolumn{2}{|l|}{$2-60 ; 26$} \\
\hline Sex; male/female & \multicolumn{2}{|l|}{$44 / 49$} \\
\hline FAB classification & \multicolumn{2}{|c|}{$\begin{array}{l}\text { M0 - } 6 \text { (6.5\%), M1 - } 13(14 \%), \text { M2 - } 19 \text { (20.4\%), M3 - } 2(2.2 \%), \text { M4 - } 29 \text { (31.2\%), } \\
\text { M5 - } 12(12.9 \%), \text { M7 - } 1(1.1 \%), \text { unspecified FAB - } 11 \text { (11.7\%) }\end{array}$} \\
\hline $\begin{array}{l}\text { Cytogenetic characteristics } \\
\text { in AML debut }\end{array}$ & $\begin{array}{l}t(8 ; 21) \\
\text { inv(16) } \\
t(15 ; 17) \\
\text { Normal karyotype } \\
\text { 0ther cytogenetic abnormalities } \\
\text { Complex karyotype }\end{array}$ & $\begin{array}{l}9(9.7 \%) \\
5(5.4 \%) \\
3(3.2 \%) \\
62(66.7 \%) \\
10(10.7 \%) \\
4(4.3 \%)\end{array}$ \\
\hline $\begin{array}{l}\text { Type of allo-HSCT: } \\
\text { Related donor } \\
\text { Unrelated } \\
\text { Haploidentical }\end{array}$ & $\begin{array}{l}16(17.2 \%) \\
67(72 \%) \\
10(10.8 \%)\end{array}$ & \\
\hline $\begin{array}{l}\text { Conditioning regimen: } \\
\text { Myeloablative } \\
\text { Nonmyeloablative }\end{array}$ & $\begin{array}{l}33(35 \%) \\
60(65 \%)\end{array}$ & \\
\hline Relapses after allo-HSCT, n (\%): & $27(28 \%)$ & \\
\hline
\end{tabular}

Table 2. Sequences of primers and TaqMan probes used in this work

\begin{tabular}{|l|l|l|l|}
\hline $\begin{array}{l}\text { Gene } \\
\text { studied }\end{array}$ & Forward primers & Reverse primers & TaqMan fluorescent probes \\
\hline BAALC & 5'-CTACAGCCCCAGGTGGAATA-3' & 5'-TTGCAGGCATTCTCTTAGCA-3' & (FAM)-ATGGCCTTCAGACCACAGAG-(BH02) \\
\hline ABL & 5-'TGGAGATAACACTCTAAGCATAACTAAAGGT-3' & 5'-GATGTAGTTGCTTGGGACCCA-3' & (J0E)-CCATTTTTGGTTGGGCTTCACACCATT-(BH01) \\
\hline
\end{tabular}

with a BioRad iQ5 instrument ("BioRad", USA). The amplification protocol was $95^{\circ} \mathrm{C}$ for $10 \mathrm{~min}$ followed by 50 cycles of heating at $95^{\circ} \mathrm{C}(15 \mathrm{sec})$, and annealing at $60^{\circ} \mathrm{C}(1 \mathrm{~min})$. The relative $B A A L C$ expression levels, or $B A A L C$ copy numbers $(\mathrm{CN})$ were determined against the housekeeping reference gene ABL1 to adjust for variations in mRNA quality and different efficiencies of cDNA synthesis. [14]. The gene expression ratio was calculated by the formula $\mathrm{CN}(B A A L C)$ / $\mathrm{CN}(\mathrm{ABL}) \times 100 \%$, and the results were expressed in percents.

\section{Statistical methods}

Statistical evaluation was performed using descriptive statistics and non-parametric correlation analysis (Spearman rank correlation quotient). In order to reveal the basal $B A A L C$ cut-off expression level for MRD monitoring, the analysis of its specificity and sensitivity compared to the reference methods was calculated using ROC-analysis. The prognostic significance of BAALC expression level estimated by plotting of OS, RFS and relapse risk curves, according to Kaplan-Meier. SPSS software version 22.0 (IBM corporation, Armonk, NY, USA) and SAS9 were used for statistical analysis.

\section{Results}

Correlation between BAALC expression level and clinical scores

In the present study, we have observed positive correlations between $B A A L C$ expression level and the number of blast 
cells in bone marrow $(\mathrm{R}=0.417, \mathrm{~N}=93, \mathrm{p}=0.000)$, and with chimeric transcripts in the favorable cytogenetic risk group (RUNX1-RUNX1T1, PML-RARa and CBFB-MYH11) $(\mathrm{R}=0.388, \mathrm{~N}=16, \mathrm{p}=0.000)$. A stronger correlation was revealed between $B A A L C$ and chimeric transcript RUNX1RUNX1T1 expression ( $\mathrm{R}=0.521, \mathrm{~N}=9, \mathrm{p}=0.000)$. Besides, in three patients, who displays PML-RAR a transcript, we observed relative lower $B A A L C$ expression profile (BAALC expression level ranged from $0.05 \%$ to $12.87 \%$ with a median $1.84 \%)$. In addition, a negative correlation was revealed for $B A A L C$ and donor chimerism level which was determined by analysis of short tandem repeats $(R=-0.257, N=93$, $\mathrm{p}=0.0001)$.

\section{Posttransplant BAALC expression monitoring for the relapse risk estimation}

The terms of relapse for the patients included into this study ranged from 24 to 400 (a median of 101) days post-transplant. BAALC expression level in the cases of posttransplant relapse was higher than in non-relapsing patients, except for the early posttransplant period (Fig. 1). The most significant difference was detected at $\mathrm{D}+60(\mathrm{p}=0.006), \mathrm{D}+90(\mathrm{p}=0.022)$, $\mathrm{D}+120(\mathrm{p}=0.008), \mathrm{D}+150(\mathrm{p}=0.006)$, and $\mathrm{D}+270(\mathrm{p}=0.006)$ after allo-HSCT.

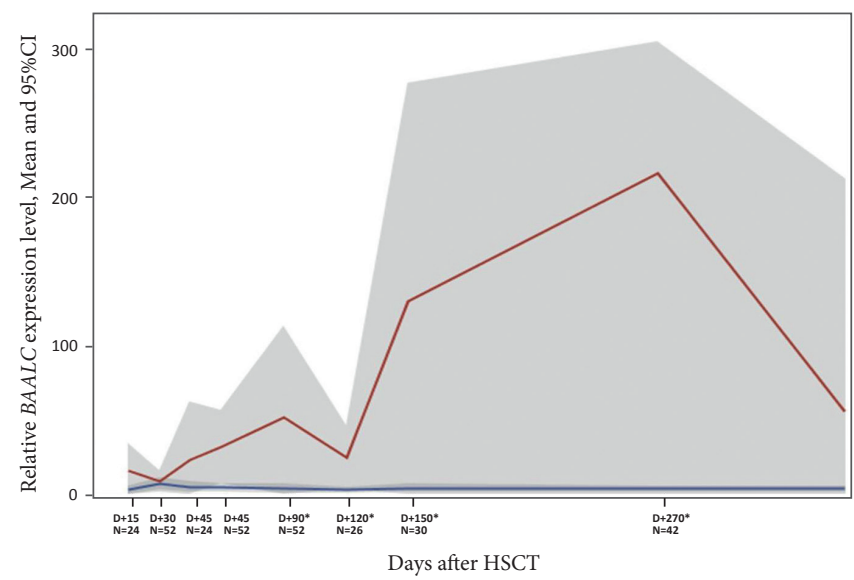

Figure 1. Time course and magnitude of BAALC expression reflects a relapse risk in subgroups of AML patients over the posttransplant period. Abscissa: days after HSCT and number of cases at each timepoint. Ordinate: Relative BAALC expression levels, \%. Red graph patients with clinical relapse in posttransplant period. Blue graph - patients without clinical relapse in posttransplant period. * $-p<0.05$. The grey-shaded space represents $95 \%$ confidence intervals

Our data indicate that BAALC expression levels in relapse-free patients did not differ significantly from those in remission state before allo-HSCT $(\mathrm{N}=69, \mathrm{p}=0.308)$, also being independent on the conditioning regimen $(\mathrm{N}=69$, $\mathrm{p}=0.199)$. The median of BAALC expression levels in the patients without post-transplant relapse was $2.6 \%$, with a maximal value of $56.7 \%$ (Fig. 2). At early terms after HSCT $(\mathrm{D}+15$ to $\mathrm{D}+30)$, the levels of BAALC expression in these patients were comparable to those in remission before HSCT $(\mathrm{p}=0.515(\mathrm{~N}=17)$ and $\mathrm{p}=0.212(\mathrm{~N}=37)$, respectively). In this respect, the basal BAALC expression level of $60 \%$ was cho-

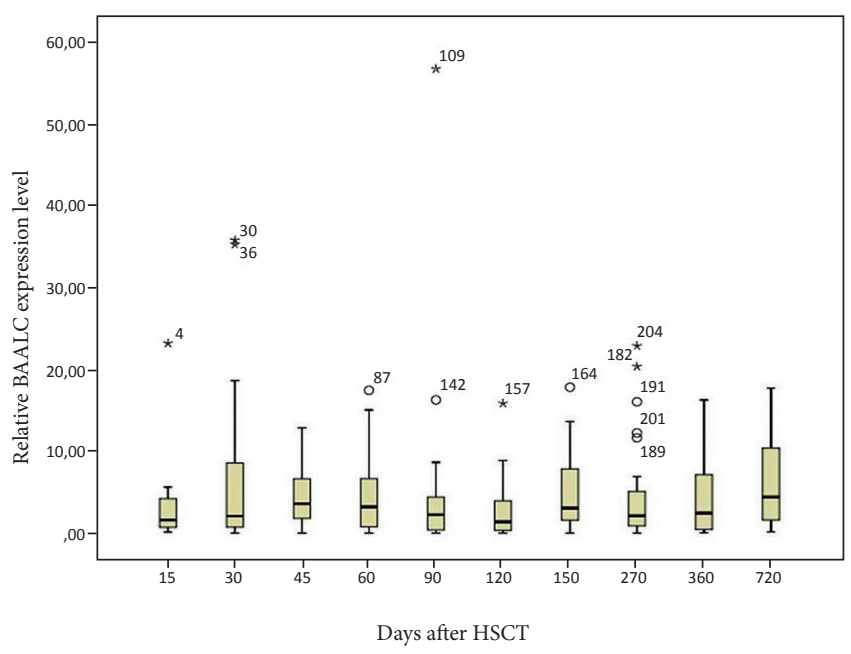

Figure 2. A variety of BAALC expression levels over posttransplant period in the patients without relapse after allo-HSCT. Asterisks represent extreme values, circles represent outlying values

sen as a common cut-off value in order to assess the BAALC prognostic significance in AML patients over the post-transplant period, because such cut-off reflects a maximal $B A A L C$ expression in non-relapsed patients.

We have also undertaken a study with individual pre-transplant cut-off values, in order to predict probability of post-transplant remission. The patients with relative $B A A L C$ expression level of $>0.5 \%$ in remission before HSCT were taken into analysis. Appropriate group of 51 patients was studied, including 16 cases of posttransplant relapse. The median $B A A L C$ expression level in patients in pre-transplant remission was 3.7, as compared to the patients relapsed after HSCT who exhibited a median pre-transplant value of 120.5 ( $\mathrm{p}=0.0001$, according to the Wilcoxon test). In absence of post-transplant relapse, $97.1 \%$ of patients did not show an increased BAALC expression by more than $0.5 \log _{10}$ (fivefold) over the post-transplant period (Fig. 3).

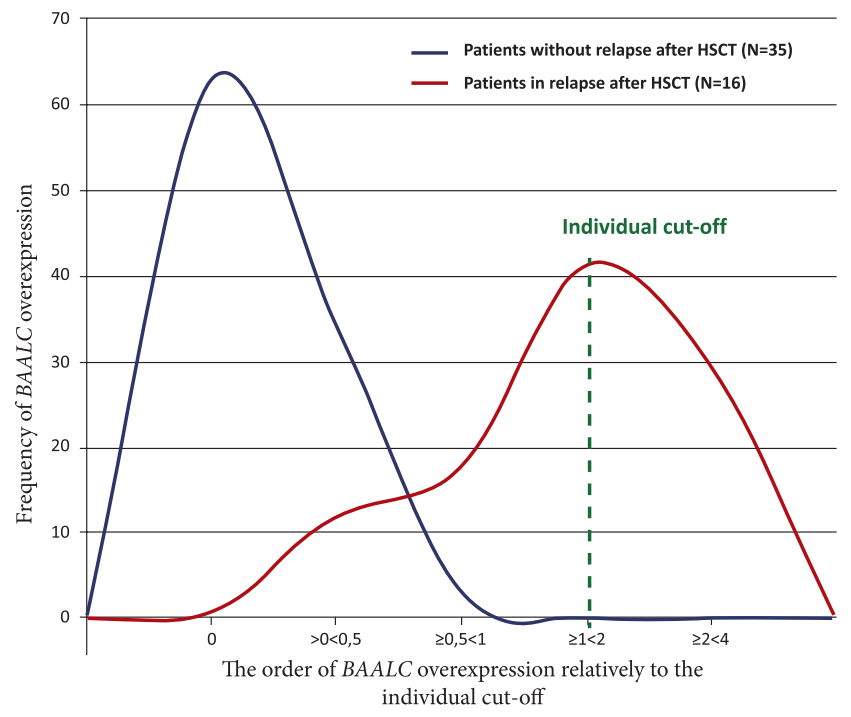

Figure 3. Changes of individual BAALC expression level in patients without relapse or in relapse after the allo-HSCT relatively to the period before transplantation. Abscissa: orders of BAALC overexpression $\left(\log _{10}\right)$ 

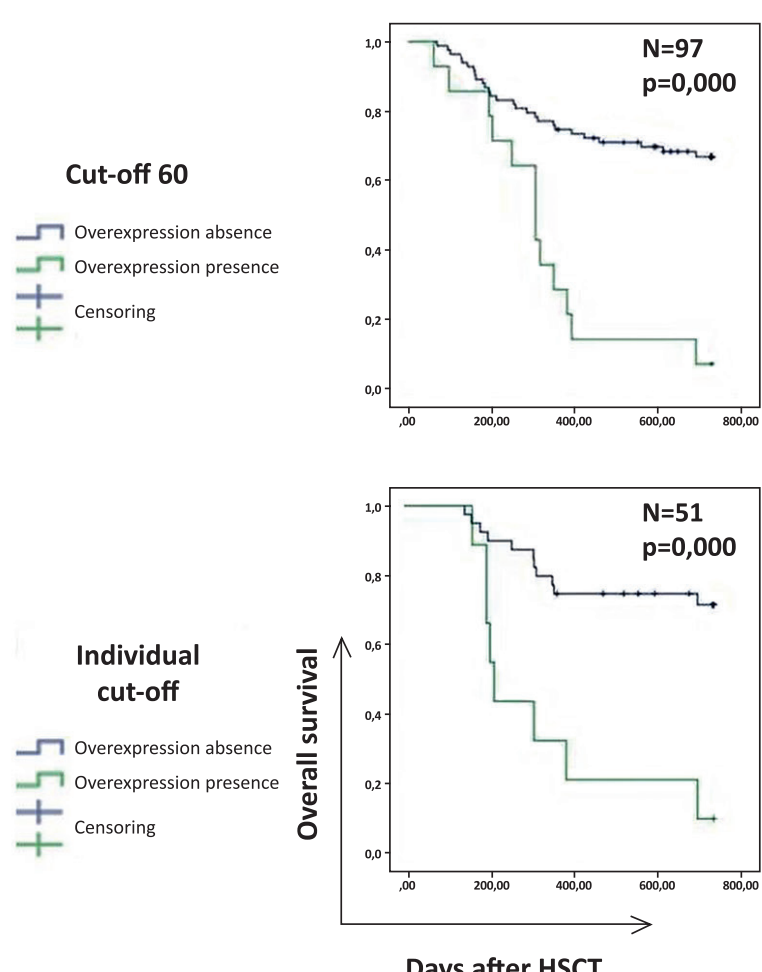

Days after HSCT
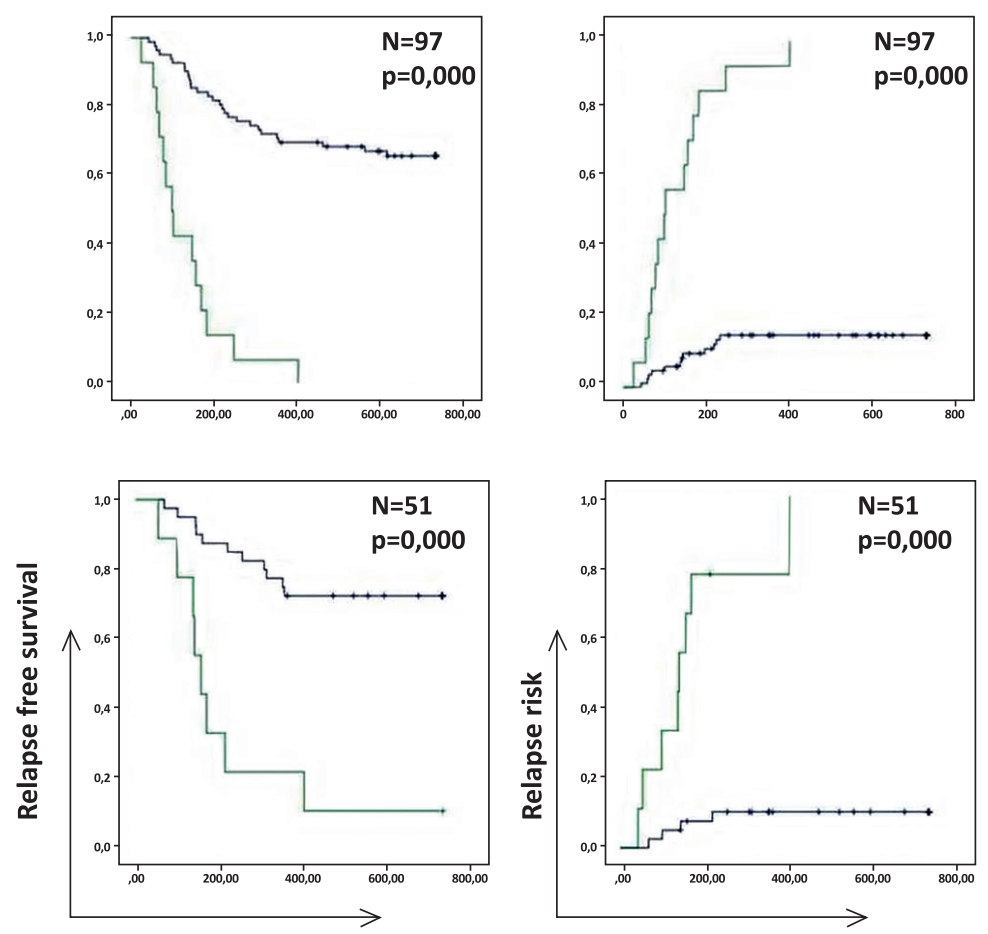

Days after HSCT

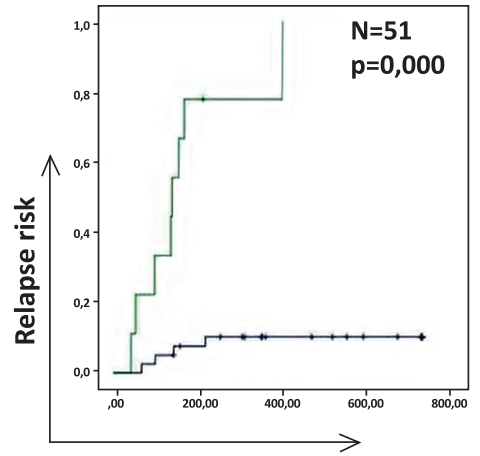

Days after HSCT

Figure 4. Kaplan-Meier curves for the time-dependent OS, RFS and relapse risk (left to right) for the subgroups with $B A A L C$ expression exceeding common cut-off level (upper boxes) or above the individual cut-off level (lower boxes), during the posttransplant period. Abscissa, days post-HSCT; ordinate, survival/relapse rates

In $88.2 \%$ patients with relapse, we observed $B A A L C$ expression level of more than for $0.5 \log _{10}$ above the individual threshold. Moreover, a rise of individual $B A A L C$ expression levels by more than one order of magnitude was registered in $80 \%$ of post-transplant relapsed patients. Such an increase was not observed in patients with relapse-free post-transplant course. Therefore, BAALC overexpression of $>1 \log _{10}$ has been chosen as an individual cut-off level for studying prognostic significance of $B A A L C$ during the post-transplant period in AML patients.

\section{BAALC overexpression: prediction for survival and relapse risk}

In the study group, expression of BAALC above the cut-off level of $60 \%$ was observed in $51.9 \%$ of relapse cases (14 of 27 patients), whereas individual increases over the cut-off value were registered in 11 relapsed patients of 14 (78.6\%).

When studying the prognostic significance of BAALC over-expression, we have revealed significant correlations between both individual and common cut-off excess and overall survival, relapse-free survival and relapse risk over a 2-year period after HSCT (Fig. 4). In cases of BAALC overexpression $>60 \%$, both OS and RFS rates were decreased to $7.1 \%$ and $0 \%$, respectively, and the relapse risk was $100 \%$. In case of $B A A L C$ over-expression above $1 \log _{10}$ higher than individual cut-offs, the OS and RFS factors were $11.1 \%$ and the relapse risk was $88.9 \%$. In particular, BAALC overexpression by $>1 \log _{10}$ over individual cutoff allows assignment of the patients to prognostically unfavorable risk group for high OS, RFS and relapse risk (Fig. 5).
Moreover, we have revealed that the pre-relapse increase of individual cutoff values proved to occur sooner than an increased common cut-off value $(>60 \%)$.

For example, BAALC expression by more than $1 \log _{10}$ over individual basal expression levels was observed in 6 of 14 relapse cases in this group (42.9\%) and it developed at 51 days (3-115) prior to clinical relapse. BAALC expression of $>60 \%$ before the clinical relapse was registered in 2 cases from 21 (9.52\%), and in both cases it was developed in 9 days before clinical symptoms of relapse.

\section{Assessing the BAALC cut-off level for reliable MRD monitoring}

Minimal residual disease (MRD) is the one of basic reasons of posttransplant relapses in AML. The most sensitive method for MRD detection is the monitoring of the patient-specific cytogenetic aberrations in leukemic cells, resulting in fusion transcripts, or genetic point mutations. However, more than a half of AML patients lack such informative genetic markers [15]. Such patient cohorts represent an ideal group for studying the significance of $B A A L C$ overexpression for MRD detection and estimation of relapse risk in post-transplant period.

Our study included assessment of cut-off level for $B A A L C$ expression aimed for MRD monitoring in the patients with chimeric transcripts. Appropriate expression levels were based on results of quantitative real-time PCR $(\mathrm{N}=17)$. By comparing BAALC expression in molecular remission $(\mathrm{MRD}=0 \%)$ and relapse $(\mathrm{MRD}>0 \%)$ using the receiver- 

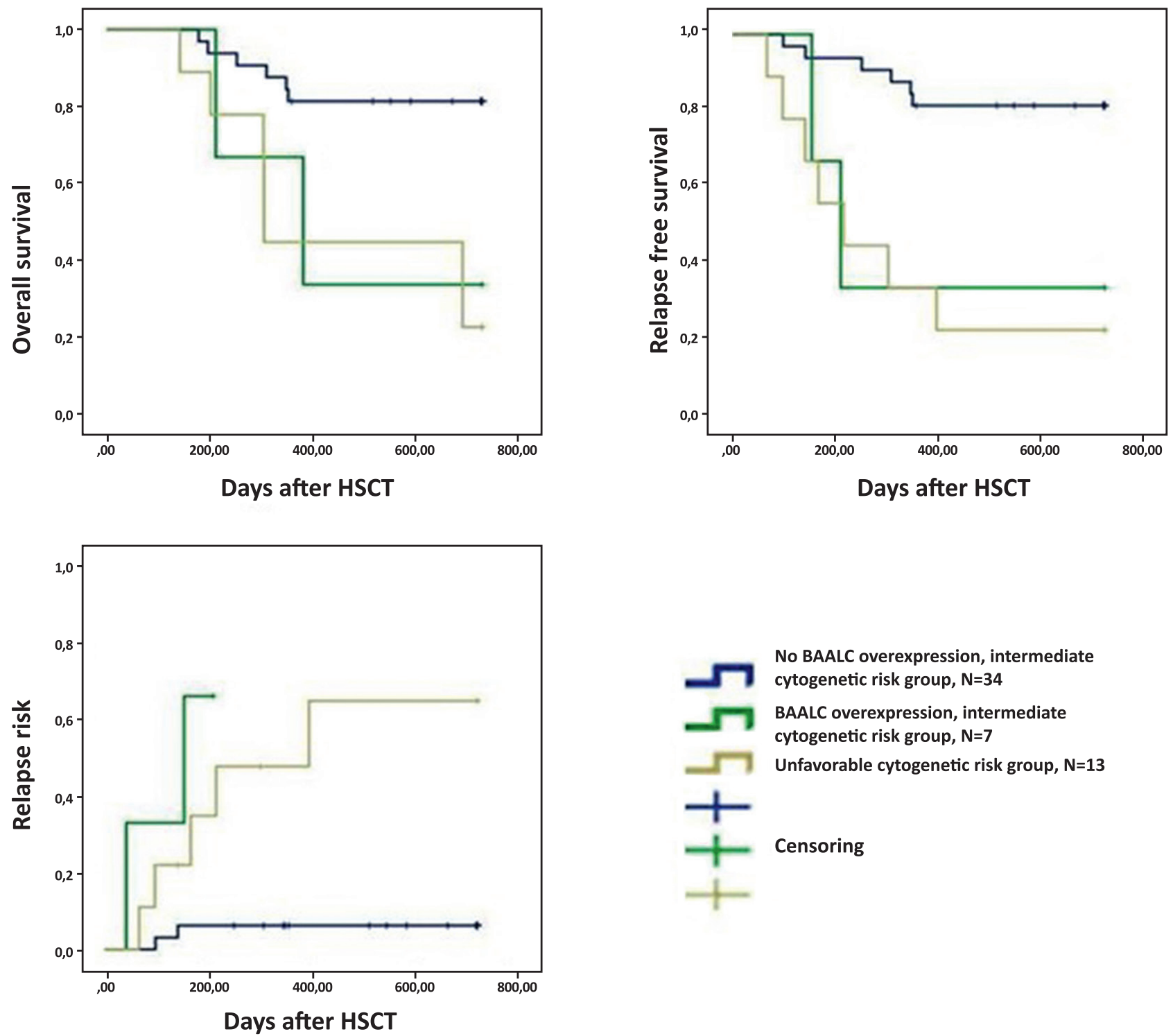

Figure 5. Prognostic significance of posttransplant BAALC expression over individual cut-offs for intermediate-risk AML group, as compared to the group of cytogenetic-based unfavorable prognosis $(N=54, p=0.000)$

operating characteristic curve (ROC) plotting method, a range of the most sensitive and specific cut-off level values was determined for clinical relapse prediction (Fig. 6A). The area under the curve (AUC) was 0.698 . The BAALC expression level at maximal sensitivity and specificity for detection of residual tumor cell was adjusted to $5.2 \%$ (sensitivity of 0.495 , and specificity of 0.914 ).

Using the generated cut-off value of 5.2\% for the entire patient cohort, we have shown that the BAALC expression exceeding such value did not significantly influence the relapse risk $(\mathrm{p}=0.071)$, overall $(\mathrm{p}=0.422)$ and relapse-free survival $(\mathrm{p}=0.244)$ after the HSCT (Fig. 6 B-D).

At the same time, the amounts of positive chimeric gene transcripts in favorable-risk patient group $(\mathrm{N}=17)$ ranging from 0.002 to $231 \%$, with a median of $0.09 \%$, were observed at the $B A A L C<5.2 \%$ expression level (Fig. 7).

\section{Discussion}

Our study aimed for evaluation of prognostic significance for the BAALC overexpression after allo-HSCT, as well as $B A A L C$ monitoring for relapse risk estimation after HSCT, and calculation of sensitivity and specificity indexes of MRD testing in AML patients with normal karyotype.

We have found positive correlations between BAALC expression levels and amounts of blast cells in bone marrow samples, and correlations with molecular cytogenetic markers in favorable AML risk group, especially, with chimeric RUNX1-RUNX1T transcript. These data well conform to the previously published analyses [16]. The low correlation quotient may be explained by the fact that BAALC expression is more typical to the least differentiated hematopoietic progenitors and blast cells that express the CD34 surface marker. However, leukemic cells in 20\% of AML cases are more differentiated, being CD34-negative, thus exhibiting 
ROC curves

A

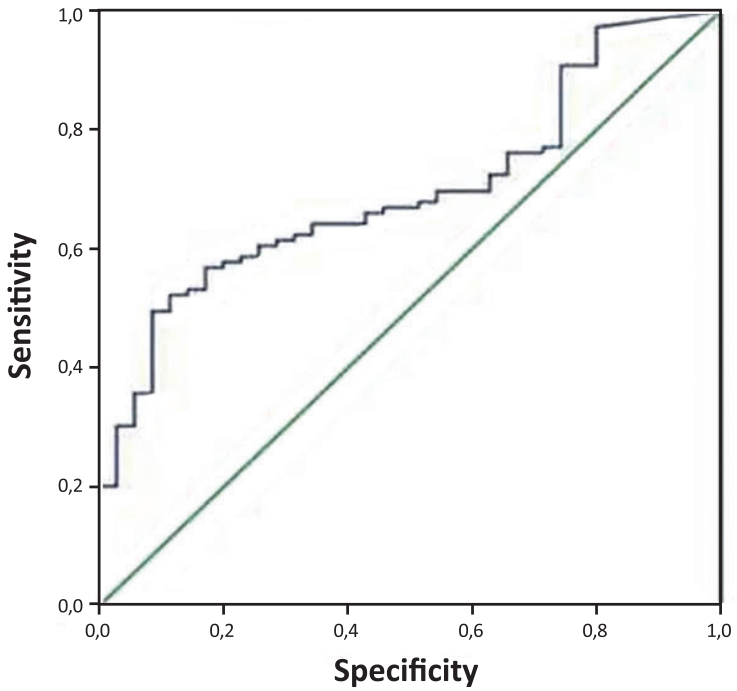

C

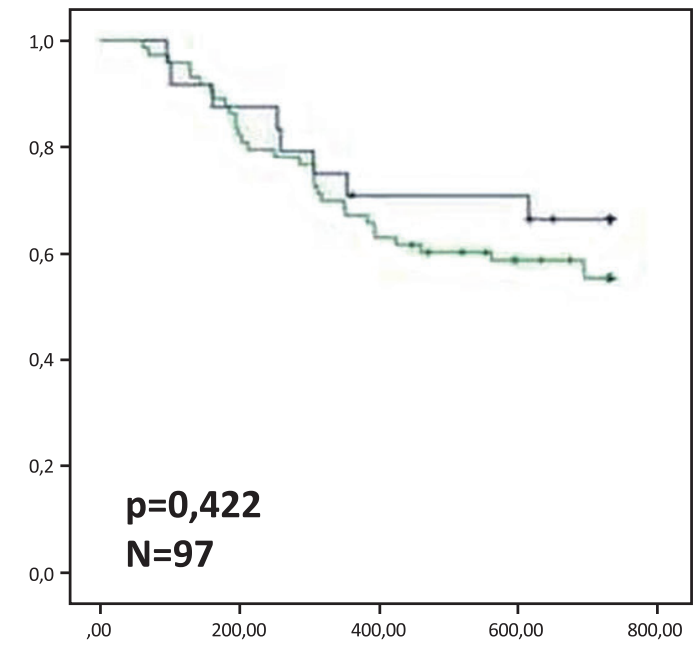

Relapse risk
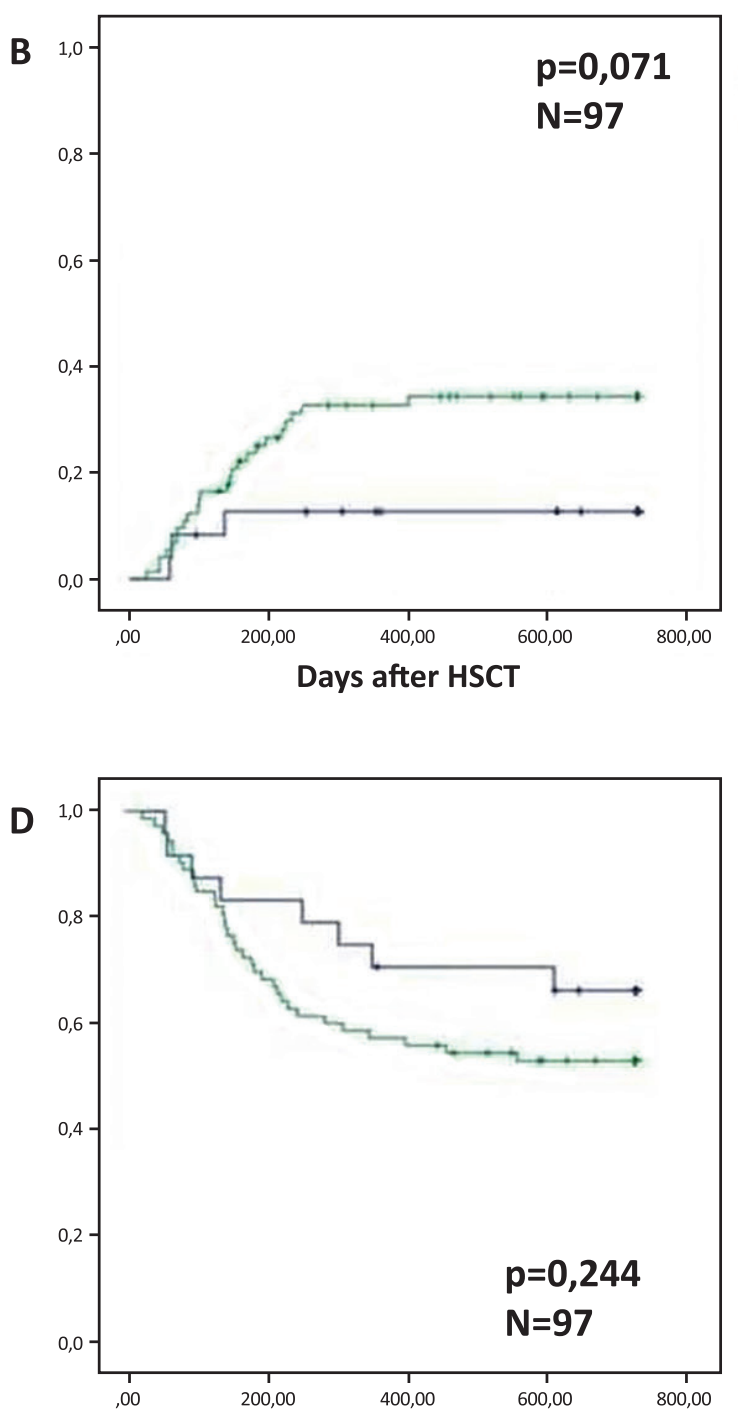

Figure 6. Graph A: estimation of basal BAALC cut-off level for MRD detection by means of ROC-analysis; $B$, influence of BAALC overexpression (BAALC $>5.2 \%$ ) on the clinical relapse risk in AML patients with normal karyotype (NK-AML) after allo-HSCT; $C$, influence of BAALC overexpression (BAALC $>5.2 \%$ ) on the 2-year 0S values of NK-AML patients; $D$, influence of BAALC overexpression (BAALC $>5.2 \%)$ on the 2-year RFS values of NK-AML patients after HSCT

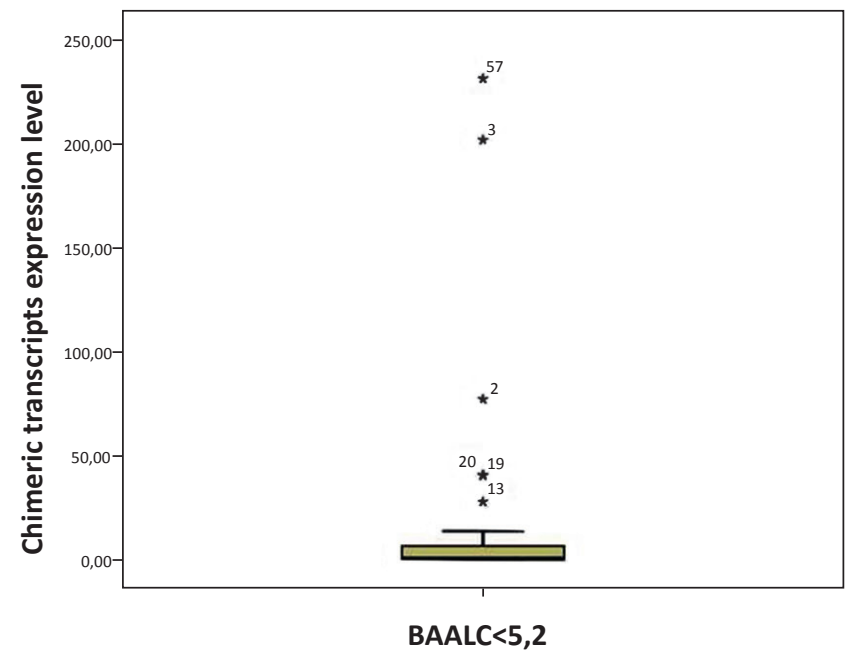

Figure 7. Expression range of mRNA fusion transcripts typical to favorable cytogenetic risk group at the BAALC expression levels of $<5.2 \%$ 
lower $B A A L C$ expression $[7,17,18]$. Stronger correlation of $B A A L C$ and RUNX1-RUNX1T1 compared to other translocations in favorable cytogenetic group can be explained by the presence of a G424T polymorphism (rs62527607) in $B A A L C$ promoter region which is found in $15 \%$ of cases. This nucleotide substitution creates an additional site for high affinity RUNX1 transcription factor binding [19, 20]. The RUNX1 transcription factor and RUNX1-RUNX1T1 chimeric protein have a similar target gene activation profile, due to identical DNA-binding domain structure, thus potentially leading to increased $B A A L C$ expression by the RUNX1-RUNX1T1 in cases of 424T allele [21]. Additional experiments are required to confirm this hypothesis.

A negative correlation between the BAALC expression level and PML-RARa fusion transcript was also discussed previously. BAALC expression level is significantly lower in acute promyelocytic leukemia (APL), exhibiting a specific PMLRARa translocation $[22,23]$. A functional role of $B A A L C$ gene in APL induction is still open to debates. However, $B A A L C$ overexpression allows to distinguish a sub-group with unfavorable disease prognosis within the high-risk APL cohort $[23,24]$.

According to several studies, BAALC overexpression above both individual and common cut-off levels is recognized as a prognostically significant factor for posttransplant relapse risk estimation, overall survival and relapse-free survival. Interestingly, in the cases of BAALC-positive AML status before HSCT, this marker remained to be informative in $89 \%$ of posttransplant relapses ( 8 from 9 cases). Overexpression of WT1 and PRAME markers in the exceptional BAALC-positive case was observed in the bone marrow sample at the posttransplant relapse. This fact is absolutely consistent with literature data [25], where BAALC gene expression is discussed as an early event in the dominant clone, which remains relatively stable through clonal evolution.

We have also used studied individual threshold values of $B A A L C$ expression before transplant, in order to predict a risk of clinical relapse after allo-HSCT. A ten-fold increase of individual BAALC expression over the median has been chosen as a cut-off value for results obtained in clinical remission before HSCT. Elevation over general cut-off value of $60 \%$ correlated with maximal risk of clinical relapse during the $1^{\text {st }}$ year post-transplant. Increased BAALC expression by one to four $\log _{10}$ (10-10 000 fold) over individual cut-off values suggested a transfer of the patient to unfavorable risk group. A feasibility of the individual BAALC expression monitoring is confirmed by increased expression of $B A A L C$ over general cut-off levels in only $51.9 \%$ of relapsed patients, whereas individual thresholds were exceeded at earlier terms before relapse, being informative in $78.6 \%$ of relapses. Such findings are in accordance with the literature data, where only $53.9 \%$ of relapsed patients had $B A A L C / A B L 1$ ratio over than $60 \%$ [25].

Referring to the scientific publications, monitoring of the $B A A L C$ expression may be useful for therapy efficiency estimation in the patients lacking specific genetic markers of tumor cells, and for prediction of molecular and clinical relapse [4, 22, 25, 26]. Applicability of BAALC expression as a MRD marker is based on its sufficient overexpression in relapse if compared to the remission values and its correlation with gene expression of AML markers, such as RUNX1-RUNX1T1, WT1 expression, other markers of normal-karyotype AML (RUNX1, FLT3-ITD, NPM1, CEBPA, MLL-PTD etc.). Our data confirm a significant difference of BAALC expression for the remission and relapse states. However, a more detailed analysis of BAALC as an MRD marker, and its comparison to the reference techniques for MRD monitoring (i.e., qPCR-based detection of chimeric gene transcripts) was performed, showing lower sensitivity of such approach to MRD detection in post-transplant period, at least, for our study group. In the absence of $B A A L C$ overexpression $(B A A L C<5.2 \%$ ), positive $M R D$ values can be observed, whereas $B A A L C$ over-expression (BAALC>5.2\%) did not significantly correlate with relapse risk, overall and relapse-free survival. Therefore, quantitative monitoring of $B A A L C$ expression could not be recommended as a universal marker of therapy efficiency in the patients with normal-karyotype AML after allo-HSCT, since a specificity of BAALC for CD34+ leukemic blasts is reduced, due to its basal expression in early hematopoietic progenitors [7, 27].

\section{Conclusion}

Summarizing our results obtained with a representative group of AML patients, we may recommend the serial quantitative $B A A L C$ monitoring for clinical relapse prediction following allogeneic hematopoietic stem cell transplantation. Tracing of BAALC expression levels and individual assignment of cut-off values can be useful not only for stratification of patients into different risk groups, but also for selection of appropriate AML therapy after allo-HSCT.

\section{Conflict of interest}

No conflicts of interest are reported.

\section{References}

1. Haferlach T, Schoch C, Löffler H, Gassmann W, Kern W, Schnittger S, Fonatsch C, Ludwig WD, Wuchter C, Schlegelberger B, Staib P, Reichle A, Kubica U, Eimermacher H, Balleisen L, Grüneisen A, Haase D, Aul C, Karow J, Lengfelder E, Wörmann B, Heinecke A, Sauerland MC, Büchner T, Hiddemann W. Morphologic dysplasia in de novo acute myeloid leukemia (AML) is related to unfavorable cytogenetics but has no independent prognostic relevance under the conditions of intensive induction therapy: results of a multiparameter analysis from the German AML Cooperative Group studies. J Clin Oncol. 2003;21(2):256-265.

2. Barrett JA and Battiwalla M. Relapse after allogeneic stem cell transplantation. Expert Rev Hematol. 2010; 3(4): 429-441.

3. Langer C, Radmacher MD, Ruppert AS, Whitman SP, Paschka P, Mrózek K, Baldus CD, Vukosavljevic T, Liu CG, Ross ME, Powell BL, de la Chapelle A, Kolitz JE, Larson RA, Marcucci G, Bloomfield CD. High BAALC expression associates with other molecular prognostic markers, poor outcome, and a distinct gene-expression signature in cytogenetically normal patients younger than 60 years with 
acute myeloid leukemia: a Cancer and Leukemia Group B (CALGB) study. Blood. 2008; 111(11): 5371-5379.

4. Yoon JH, Kim HJ, Shin SH, Yahng SA, Lee SE, Cho BS, Eom KS, Kim YJ, Lee S, Min CK, Cho SG, Kim DW, Lee JW, Min WS, Park CW, Lim JH. BAALC and WT1 expressions from diagnosis to hematopoietic stem cell transplantation: consecutive monitoring in adult patients with core-binding-factor-positive AML. Eur J Haematol. 2013;91(2):112121.

5. Jentzsch M, Bill M, Grimm J, Schulz J, Goldmann K, Beinicke S, Häntschel J, Pönisch W, Franke GN, Vucinic V, Behre G, Lange T, Niederwieser D, and Schwind S. High BAALC copy numbers in peripheral blood prior to allogeneic transplantation predict early relapse in acute myeloid leukemia patients. Oncotarget. 2017; 8(50): 87944-87954.

6. Tanner SM, Austin JL, Leone G, Rush LJ, Plass C, Heinonen K, Mrózek K, Sill H, Knuutila S, Kolitz JE, Archer KJ, Caligiuri MA, Bloomfield CD, and de la Chapelle A. BAALC, the human member of a novel mammalian neuroectoderm gene lineage, is implicated in hematopoiesis and acute leukemia. Proc Natl Acad Sci U S A. 2001; 98(24): 13901-13906.

7. Baldus CD, Tanner SM, Ruppert AS, Whitman SP, Archer KJ, Marcucci G, Caligiuri MA, Carroll AJ, Vardiman JW, Powell BL, Allen SL, Moore JO, Larson RA, Kolitz JE, de la Chapelle A, Bloomfield CD. BAALC expression predicts clinical outcome of de novo acute myeloid leukemia patients with normal cytogenetics: a Cancer and Leukemia Group B Study. Blood. 2003;102(5):1613-1618.

8. Ferrara F, Palmieri S, Leoni F. Clinically useful prognostic factors in acute myeloid leukemia. Rev Oncol Hematol. 2008;66(3):181-193.

9. Baldus CD, Thiede C, Soucek S, Bloomfield CD, Thiel E, Ehninger G. BAALC expression and FLT3 internal tandem duplication mutations in acute myeloid leukemia patients with normal cytogenetics: prognostic implications. J Clin Oncol. 2006;24(5):790-797.

10. Morita K, Masamoto Y, Kataoka K, Koya J, Kagoya Y, Yashiroda H, Sato T, Murata S, Kurokawa M. BAALC potentiates oncogenic ERK pathway through interactions with MEKK1 and KLF4. Leukemia. 2015;29(11):2248-2456.

11. Heuser M, Berg T, Kuchenbauer F, Lai CK, Park G, Fung S, Lin G, Leung M, Krauter J, Ganser A, Humphries RK. Functional role of BAALC in leukemogenesis. Leukemia. 2012;26(3):532-536.

12. Eisfeld AK, Schwind S, Patel R, Huang X, Santhanam R, Walker CJ, Markowitz J, Hoag KW, Jarvinen TM, Leffel B, Perrotti D, Carson WE 3rd, Marcucci G, Bloomfield CD, de la Chapelle A. Intronic miR-3151 within BAALC drives leukemogenesis by deregulating the TP53 pathway. Sci Signal. 2014;7(321):ra36.

13. Xu B, Chen G, Shi P, Guo X, Xiao P, Wang W, Zhou S. shRNA-Mediated BAALC knockdown affects proliferation and apoptosis in human acute myeloid leukemia cells. Hematology. 2012;17(1):35-40.
14. Schmittgen TD, Livak KJ. Analyzing real-time PCR data by the comparative C(T) method. Nat Protoc. 2008;3(6):11011108 .

15. Saultz JN, Garzon R. Acute myeloid leukemia: A concise review. J Clin Med. 2016; 5(3). pii: E33. doi: 10.3390/ jcm5030033.

16. Qi X, Shen Y, Cen J, Chen H, Sun Y, Sheng H, Wang Y, and Chena Z. Up-regulation of BAALC gene may be an important alteration in AML-M2 patients with $\mathrm{t}(8 ; 21)$ translocation. J Cell Mol Med. 2008; 12(6a): 2301-2304.

17. Oyan AM, TH, Jonassen I, Ulvestad E, Gjertsen BT, Kalland KH, Bruserud O. CD34 expression in native human acute myelogenous leukemia blasts: differences in CD34 membrane molecule expression are associated with different gene expression profiles. Cytometry B Clin Cytom. 2005;64(1):18-27.

18. Schuurhuis GJ, Kelder A, Terwijn M, Rutten AP, Smit L, Zweegman S, Ossenkoppele G. The prognostic value of CD34 expression in acute myeloid leukemia. A mystery solved. Blood. 2010; 116 (21):2725.

19. Eisfeld AK, Marcucci G, Liyanarachchi S, Döhner K, Schwind S, Maharry K, Leffel B, Döhner H, Radmacher MD, Bloomfield CD, Tanner SM, and de la Chapellea A. Heritable polymorphism predisposes to high BAALC expression in acute myeloid leukemia. Proc Natl Acad Sci USA. 2012; 109(17): 6668-6673.

20. Nadimi M, Rahgozar S, Moafi A, Tavassoli M, Mesrian Tanha H. Evaluation of rs62527607 [GT] single nucleotide polymorphism located in BAALC gene in children with acute leukemia using mismatch PCR-RFLP. Cancer Genet. 2016;209(7-8):348-353.

21. Lam $\mathrm{K}$ and Zhang DE. RUNX1 and RUNX1-ETO: roles in hematopoiesis and leukemogenesis. Front Biosci. 2012;17:1120-1139.

22. Najima Y, Ohashi K, Kawamura M, Onozuka Y, Yamaguchi T, Akiyama H, Sakamaki H. Molecular monitoring of BAALC expression in patients with CD34-positive acute leukemia. Int J Hematol. 2010;91(4):636-645.

23. Lucena-Araujo AR, Pereira-Martins DA, Koury LS, Franca-Neto PL, Coelho-Silva JL, de Deus Wagatsuma VM, Melo RAM, Bittencourt R, Pagnano K, Pasquini R, Chiattone CS, Fagundes EM, Chauffaille ML, Schrier SL, Tallman MS, Ribeiro RC, Grimwade D, Ganser A, Löwenberg B, Lo-Coco F,Sanz MA, Berliner N, Rego EM. Clinical impact of BAALC expression in high-risk acute promyelocytic leukemia. Blood Adv. 2017; 1(21): 1807-1814.

24. Nolte F, Hecht A, Reinwald M, Nowak D, Nowak V, Hanfstein B, Faldum A, Büchner T, Spiekermann K, Sauerland C, Hofmann WK, Lengfelder E. In acute promyelocytic leukemia (APL) low BAALC gene expression identifies a patient group with favorable overall survival and improved relapse free survival. Leuk Res. 2013;37(4):378-382.

25. Weber S, Haferlach T, Alpermann T, Perglerová K, Schnittger S, Haferlach C, Kern W. Feasibility of BAALC gene expression for detection of minimal residual disease 
and risk stratification in normal karyotype acute myeloid leukaemia. Br J Haematol. 2016;175(5):904-916.

26. Weber S, Alpermann T, Dicker F, Jeromin S, Nadarajah N, Eder C, Fasan A, Kohlmann A, Meggendorfer M,Haferlach C, Kern W, Haferlach T, Schnittger S. BAALC expression: a suitable marker for prognostic risk stratification and detection of residual disease in cytogenetically normal acute myeloid leukemia. Blood Cancer J. 2014; 4(1): e173.
27. Eid MA, Attia M, Abdou S, El-Shazly SF, Elahwal L, Farrag W, Mahmoud L. BAALC and ERG expression in acute myeloid leukemia with normal karyotype: impact on prognosis. Int J Lab Hematol. 2010;32(2):197-205.

\title{
Прогностическое значение гиперэкспрессии BAALC у больных острым миелобластным лейкозом в посттрансплантационном периоде
}

\author{
Алена И. Шакирова, Ильдар М. Бархатов, Анна И. Чуркина, Иван С. Моисеев, Татьяна Л. Гиндина, \\ Сергей Н. Бондаренко, Борис В. Афанасьев \\ НИИ детской онкологии, гематологии и трансплантологии им. Р. Горбачевой, кафедра гематологии, трансфузиологии \\ и трансплантологии Первого Санкт-Петербургского государственного медицинского университета им. И. П. Павлова, \\ Санкт-Петербург, Российская Федерация
}

\section{Резюме}

Острый миелоидный лейкоз (ОМЛ) представляет собой гетерогенное клональное заболевание крови опухолевой природы. Для пациентов с ОМЛ промежуточной цитогенетической группы риска, которая является гетерогенной по мутационному статусу целого ряда генов (FLT3, NPM1, CEBPA и т.д.), прогнозирование течения заболевания, оценка риска развития рецидива и выбор оптимальной терапии затруднены. В связи с этим поиск новых молекулярных маркеров, имеющих большое прогностическое значение, а так же полезных в аспекте оценки риска развития рецидива у пациентов с ОМЛ, лишенных крупных цитогенетических аномалий, является одной из приоритетных задач молекулярной онкогематологии. Для оценки применимости мониторинга уровня экспрессии гена BAALC (Brain And Acute Leukemia, Cytoplasmic) для предикции развития рецидива, оценки чувствительности и специфичности метода мониторинга BAALC с целью оценки эффективности терапии, мы проанализировали прогностическое значение гиперэкспрессии гена $B A A L C$ у 93 пациентов с ОМЛ в посттрансплантационном периоде. В свежих образцах костного мозга пациентов методом количественной ПЦР в режиме реального времени определялся уровень экспрессии гена BAALC. Пациенты были подразделены на группы низкой и высокой экспрессии $B A A L C$ на основании общего и индивидуального пороговых уровней экспрессии. Мы заключили, что гиперэкспрессия BAALC выше индивидуального и общего порогового уровней является прогностически значимым фактором для оценки риска развития рецидива в посттрансплантационном периоде, общей и безрецидивной выживаемости. Однако более детальный анализ BAALC как маркера эффективности терапии и его сравнение с референтными методами мониторинга минимальной остаточной болезни (такими как детекция химерных транскриптов генов методом количественной ПЦР в режиме реального времени) показал более низкую чувствительность такого подхода к мониторингу МОБ в посттрансплантационном периоде, по меньшей мере на примере исследуемой выборки пациентов. Частый мониторинг уровня экспрессии гена $B A A L C$ может быть рекомендован для предикции развития клинико-гематологического рецидива в ходе посттрансплантационного периода у пациентов с ОМЛ.

\section{Ключевые слова}

Острый миелобластный лейкоз, BAALC, экспрессия гена, клинический прогноз, минимальная остаточная болезнь. 